The Version of Record of this manuscript has been published and is available in the Journal on the Use of Force and International Law, Spring/Summer 2018, http://www.tandfonline.com/, https://doi.org/10.1080/20531702.2018.1448156

\title{
Beyond rhetoric? Evaluating the Responsibility to Protect as a norm of humanitarian intervention
}

Graham Melling

Senior Lecturer in Law, Lincoln Law School, University of Lincoln, Lincoln, UK

CONTACT: gmelling@lincoln.ac.uk

\begin{abstract}
The purpose of this article is to examine whether, after 16 years or more of its development, R2P has emerged as an international norm of intervention. As an idea, it is clear that $\mathrm{R} 2 \mathrm{P}$ has a considerable degree of prominence within international discourse. As will be shown in this article, there has been much work undertaken in the development of its language and conceptual framework over the years. However, whilst this architecture is important to the process of its development as an international norm, it will be argued that more is needed to support the claim that R2P has fully emerged as an international norm, i.e. R2P's capacity to influence and shape the decision-making of states.
\end{abstract}

\section{KEYWORDS}

Responsibility to Protect; R2P; international law; norm; humanitarian intervention; Syria; Libya; UK; internalisation

\section{Introduction}

Since its conception, the Responsibility to Protect (R2P), a concept of humanitarian protection (Pillar 1), prevention (Pillar 2) and intervention (Pillar 3), has been much heralded, much discussed and much criticised with what at best could be described as a mixed record of success. There has been a surfeit of claim, counter-claim, assertion and counter-assertion about both R2P's ideational value and effectiveness. As a human rights policy or doctrine of human security, it has been strongly promoted as an international norm. R2P has been conceptualised and re-affirmed in a series of United Nations (UN) General Assembly resolutions beginning with the much heralded World Outcome Document of 2005. It has been discussed, supported 
The Version of Record of this manuscript has been published and is available in the Journal on the Use of Force and International Law, Spring/Summer 2018, http://www.tandfonline.com/, https://doi.org/10.1080/20531702.2018.1448156

and criticised widely across the international community - from state capital to international organisation. ${ }^{1}$ However, in spite of the prominence with which R2P has been promoted and acclaimed, pertinent questions still remain about, if not its value as an idea, then certainly its position and its influence as an international norm in shaping the decision-making of states. This is particularly the case with the operation of its most controversial aspect and the focus of analysis in this article, its Pillar 3: this encompasses the role and responsibility of the international community to react and use military intervention where the humanitarian situation demands such, due to a state's perpetration of, or inability to prevent the perpetration of, mass atrocity crimes against its population (in particular genocide, war crimes, ethnic cleansing and crimes against humanity). ${ }^{2}$ R2P, therefore, could be viewed as acclaiming a norm of humanitarian intervention; however, this is not to confuse the conceptual parameters of R2P with the controversial doctrine of humanitarian intervention. A key distinction is that the doctrine of humanitarian intervention became synonymous with a claim to unilateral

\footnotetext{
${ }^{1}$ See Alex J Bellamy, 'The Responsibility to Protect: Added Value or Hot Air?' (2013) 48(3) Cooperation \& Conflict 334 (a leading scholar on R2P, noting that '[d]espite (or perhaps because) the rapid rise of RtoP... to a principle reaffirmed by the UN Security Council and utilised by the body in its response to crises in Sudan, Libya, Côte d'Ivoire, South Sudan and Yemen, RtoP has been subjected to criticism from a handful of states and a significantly larger number of scholars.'). See also Alex J Bellamy, Global Politics and the Responsibility to Protect: From Words to Deeds (Routledge, 2011); Alex J Bellamy, 'Responsibility to Protect or Trojan Horse? The Crisis in Darfur and Humanitarian Intervention after Iraq' (2005) 19(2) Ethics \& International Affairs 31; Alex J Bellamy, The Responsibility to Protect: Towards a 'Living Reality', Report written for the United Nations Association-UK www.una.org.uk/sites/default/files/The\%20Responsibility\%20to\%20Protect\%20Towards\%20a\%20Living\%20 Reality\%20-\%20Professor\%20Alex\%20Bellamy.pdf (accessed 27 January 2016); Gareth Evans, 'Responding to Mass Atrocity Crimes: The "Responsibility to Protect” After Libya', Chatham House (6th October 2011) www.chathamhouse.org/publications/papers/view/178795 (transcript of speech). See generally, Aidan Hehir, Humanitarian Intervention: An Introduction (Palgrave MacMillan, 2013); Silva D Kantareva, 'The Responsibility to Protect: Issues of Legal Formulation and Practical Application' (2011-2012) 6(1) Interdisciplinary Journal of Human Rights Law 1; Justin Morris, 'Libya and Syria: R2P and the Spectre of the Swinging Pendulum' (2013) 89(5) International Affairs 1265; John F Murphy, 'Responsibility to Protect (R2P) Comes of Age? A Sceptics View' (2012) 18(2) ILSA Journal of International and Comparative Law 413; Ved P Nanda, 'From Paralysis in Rwanda to Bold Moves in Libya: Emergence of the "Responsibility to Protect" Norm under International Law Is the International Community Ready for It?’ (2011) 34(1) Houston Journal of International Law 1; Anne Peters, 'The Security Council's Responsibility to Protect' (2011) 8 International Organisations Law Review 15; Carsten Stahn, 'Responsibility to Protect: Political Rhetoric or Emerging Legal Norm?' (2007) 101(1) American Journal of International Law 99; Ramesh Thakur, 'R2P after Libya and Syria: Engaging Emerging Powers' (Spring 2013) The Washington Quarterly 61; Rachel Van Landingham, 'Politics or Law? The Dual Nature of the Responsibility to Protect' (2012) 41(1) Denver Journal of International Law and Policy 63; Susan Breau, The Responsibility to Protect in International Law: An Emerging Paradigm Shift (Routledge, 2016); Andrew Garwood-Gowers, 'China's "Responsible Protection" Concept: Reinterpreting the Responsibility to Protect (R2P) and Military Intervention for Humanitarian Purposes’ (2016) 6 Asian Journal of International Law 89.

${ }^{2}$ Throughout the remainder of this article the term 'R2P' is used to refer solely to the Pillar 3 intervention aspect of the doctrine, unless otherwise indicated.
} 
The Version of Record of this manuscript has been published and is available in the Journal on the Use of Force and International Law, Spring/Summer 2018, http://www.tandfonline.com/, https://doi.org/10.1080/20531702.2018.1448156

intervention by states, ${ }^{3}$ whereas the operation of intervention under R2P requires Security Council authorisation.

In particular, as one looks out on the ongoing humanitarian crisis within Syria one is left questioning whether R2P has had any meaningful impact in shaping the international community's response towards the perpetration of mass atrocities. In many respects, when the international community began the dialogue around the question of the international community response to mass atrocity situations back in the year 2000, a description of the events in Syria over the course of the last five years would have been considered a perfect case study for R2P, particularly with respect to it shaping the response of the international community and its responsibility to intervene through the UN Security Council. However, when one looks closely at the role played by R2P in the Security Council's response to Syria it would seem that R2P has had, at most, a limited role. ${ }^{4}$

The purpose of this article is to examine whether, after 16 years or more of its development, R2P has emerged as an international norm of intervention. As an idea, it is clear that R2P has a considerable degree of prominence within international discourse. As will be discussed, there has been much work undertaken in the development of its language and conceptual framework over the years. However, whilst this architecture is important to the process of its development as an international norm, it will be argued herein that more is needed to support the claim that R2P has fully emerged as an international norm, i.e. R2P's capacity to influence and shape the decision-making of states. Employing Finnemore and Sikkink's analytical framework for the 'norm life-cycle', ${ }^{5}$ this article argues that there are three phases of R2P's norm emergence that must be analysed to reach a full understanding of R2P's impact as an international norm - first, the emergence of the norm, secondly its embeddedness at international level and, third, the internalisation of the norm by key states. It is contended that it is the degree to which the norm is internalised and impacts upon states' decision-making that properly determines whether R2P has emerged as an international norm. Undertaking this analysis is a complex and largely imprecise exercise because, as Morris notes, 'internalisation

\footnotetext{
${ }^{3}$ See for example the UK claim to the existence of a right of humanitarian intervention within international law in 'Human Rights', Foreign and Commonwealth Office Annual Report 2000; Bellamy, 'Responsibility to Protect or Trojan Horse? (n 1) 33.

${ }^{4}$ Of course, Syria is a hard case: it is a situation of considerable and increasing complexity. Syria is not the principal focus of this article, although certainly forms a telling backdrop to it. For a comprehensive overview of the complexity of the situation in Syria, see the informative Chatham House, 'War in Syria', www.chathamhouse.org/research/regions/middle-east-and-north-africa/war-in-syria. See also Breau (n 1) 255.

${ }^{5}$ Martha Finnemore and Kathryn Sikkink, 'International Norm Dynamics and Political Change' (1998) 52(4) International Organisation 887.
} 
The Version of Record of this manuscript has been published and is available in the Journal on the Use of Force and International Law, Spring/Summer 2018, http://www.tandfonline.com/, https://doi.org/10.1080/20531702.2018.1448156

... [is] variable and hard to measure; and consequently, it is rarely possible to be certain how strong a justification for action of a particular norm will provide. ${ }^{6}$ That said, to help assess the degree of internalisation of R2P by states one will look to the examine the role R2P has played in the decision-making of key member states, through examining the responses and actions of the Security Council with respect to the situations in Libya, the Côte d'Ivoire and Syria. This is because, as Finnemore and Sikkink note, 'norms by definition embody a quality of "oughtness" and shared moral assessment', thereby 'norms prompt justifications for action and leave an extensive trail of communication among actors'. ${ }^{7}$ This part of the evaluation will therefore involve analysis of official records of Security Council resolutions and their corresponding meetings to assess the degree of influence exerted by R2P in state's deliberations about how to respond to these situations.

Following this introduction, this article consists of four sections. The next section will examine the dynamics of norm emergence as are applied in this article. Section III will provide an outline of the emergence of the concept of R2P. Section IV considers the extent to which R2P can be considered to be embedded at the international level. Section $V$ will then examine the extent to which R2P has been internalised in the decision-making of key states within the international system; namely the member states of the UN Security Council and, in particular, the five permanent members. In the conclusion, it will be argued that whilst R2P may have strong ideational value at the international level with considerable embeddness, as a 'norm' of intervention, however, it remains highly contestable even after 16 years of its development.

\section{R2P: norm dynamics}

The definition of the term 'norm' as used in this article is a 'standard of appropriate behaviour for actors with a given identity', ${ }^{8}$ with the 'identity' of the actors in this case being states in the international community. Because norms involve 'standards of appropriate behaviour', they embody a quality of 'oughtness' representing a 'shared moral assessment'. ${ }^{9}$ R2P would certainly fall into this characterisation as the development of the doctrine is clearly intended to shape states' choices with respect to the idea of responsibility of states to the idea of human

\footnotetext{
${ }^{6}$ Morris (n 1) 1267.

${ }^{7}$ Finnemore and Sikkink (n 5) 892.

${ }^{8}$ Ibid, 891; Cf, Andrew P Cortell and James W Davis, Jr, 'How Do International Institutions Matter? The Domestic Impact of International Rules and Norms' (1996) 40(4) International Studies Quarterly 451, 452 ('Norms represent "standards of behaviour defined in terms of rights and obligations"' ').

${ }^{9}$ Finnemore and Sikkink (n 5) 892.
} 
The Version of Record of this manuscript has been published and is available in the Journal on the Use of Force and International Law, Spring/Summer 2018, http://www.tandfonline.com/, https://doi.org/10.1080/20531702.2018.1448156

security and the protection of citizens. An implicit, yet key, feature of a norm, however, is its capacity to influence behavioural change by actors. Taking this as our starting point the key question becomes: how do we identify R2P as a norm? Finnemore and Sikkink point out that '[w]e can only have indirect evidence of norms just as we can only have indirect evidence of most other motivations for political action (interests or threats, for example). ${ }^{10}$ One approach that can be taken is to examine the extent to which R2P shapes state behaviour through its decision-making by assessing the degree to which the norm constitutes a 'justification for action'. ${ }^{11}$ This involves consideration of where R2P has been used as an explanation for member states of the Security Council's decision-making and reason for action.

Applying Finnemore and Sikkink's model of the 'norm life-cycle', in order to identify R2P as a norm would require three phases of the 'norm life-cycle' to be completed - first, the emergence of the norm, secondly its embeddedness at international level and, third, the internalisation of the norm by key states. ${ }^{12}$ According to Finnemore and Sikkink the first phase consists of persuasion by norm entrepreneurs that attempt to convince a critical mass of states, known as 'norm leaders', to embrace the norm. The second phase is characterised as a process of 'imitation', whereby 'norm leaders' attempt to convince other states within the international system to become norm followers. Once enough states have become convinced, this leads to what is described as a 'norm cascade' throughout the system as the norm becomes more and more accepted as 'standard of appropriate behaviour'. In the third phase internalisation of the norm occurs, whereby states identify with its normative prescription regarding their conduct. Through this process the norm becomes influential in state decision-making and shaping state behaviour. At the far end of this third phase the norm acquires a 'taken- for-granted quality'. ${ }^{13}$

The first thing to note is that it is not uncommon for a state to appear to endorse a norm and yet take no action internally with respect to that norm. For example, states may provide fulsome rhetorical support and acclamation for the emergence and development of a norm through the auspices of the UN. This could involve support for General Assembly resolutions embodying the norm. Where the norm is developed through a series of interactions at the international level this can, in time, lead to the norm becoming embedded in the international system through a process of 'norm cascade.'14 'Norm cascade' represents the 'broad norm

\footnotetext{
${ }^{10}$ Ibid.

${ }^{11}$ Ibid.

12 Ibid, 895.

${ }^{13}$ Ibid.

${ }^{14}$ Ibid.
} 
The Version of Record of this manuscript has been published and is available in the Journal on the Use of Force and International Law, Spring/Summer 2018, http://www.tandfonline.com/, https://doi.org/10.1080/20531702.2018.1448156

acceptance' which leads to the norm becoming the 'prevailing standard of appropriateness' ${ }^{15}$ But without a sufficient level of internalisation, the norm remains an aspirational statement, rather than a prescriptive formula of how a state must act (or refrain from acting). Therefore, the greater the 'norm cascade' and internalization of the norm among states, the greater the influence the norm will have upon state behaviour.

Finnemore and Sikkink's conceptualisation of the dynamic of norm emergence and establishment is not too far removed from the way in which an international lawyer would understand the formation and establishment of customary international law. It would seem, simply put, that the concepts of cascade and internalisation operate similarly to the customary international law requirements of state practice and opinio juris. The idea of norm cascade throughout the international community reflects a similar requirement of state practice. Where a cascading norm achieves a sufficient degree of internalisation 'norms acquire a taken-forgranted quality'. ${ }^{16}$ In the same way, with the formation of customary international law, in order for state practice to become law there must be a belief by states that the state practice constitutes law - put in norm dynamic terms, the state practice has a taken for granted quality as law. This is because in respect of both the emergence of a norm and customary international law a state can appear to endorse a norm (state practice) and yet take no action internally with respect to that norm (opinio juris). Without a sufficient level of internalisation (opinio juris) the norm (state practice) remains an aspirational statement, rather than a prescriptive formula of how a state must act/not act.

It should be noted that the impact of a norm in influencing the decision-making of states depends upon the extent to which that norm is embedded within what is often a highly contested normative space. ${ }^{17}$ Finnemore and Sikkink point out that where new norms emerge they 'never enter a normative vacuum' but instead tend to emerge in a 'highly contested narrative space where they must compete with other norms and perceptions of interest. ${ }^{18}$ These existing norms

\footnotetext{
15 Ibid.

${ }^{16}$ Ibid.

${ }^{17}$ Morris (n 1) 1267.

18 Finnemore and Sikkink (n 5) 897. Due to the politics of the Security Council and, in particular, the five permanent members, it is true to say that the possibility of humanitarian intervention being authorised has been severely limited. Broadly characterised, polarisation exists within the permanent members between observing the classic Grotian values of state sovereignty and non-intervention (Russia and China), and the more progressive protection of human rights and humanitarian values (US, UK and France). In particular, Russia and China (along with other non-Western states) have carried the concern that the intervention aspect of R2P might be used by the powerful Western states to disguise the pursuit of other strategic objectives. The political machinations of the Security Council are clearly a central feature of most analysis of the effectiveness of R2P because the Council retains control over its operation. See Garwood-Gowers (n 1) 94.
} 
The Version of Record of this manuscript has been published and is available in the Journal on the Use of Force and International Law, Spring/Summer 2018, http://www.tandfonline.com/, https://doi.org/10.1080/20531702.2018.1448156

will most often be firmly embedded within the existing system. In the case of R2P, for example, it has continuously been counterpoised against the key international norm of state sovereignty in the development of its normative content, ${ }^{19}$ in addition to the existing UN Charter paradigm for any intervention.

In sum, evaluating $\mathrm{R} 2 \mathrm{P}$ as a norm is achieved not from measuring the degree of international acclaim that it has received, but requires assessing the degree to which the norm is internalized by states and thereby leads to behavioural change by states. ${ }^{20}$ Moreover, Finnemore and Sikkink argue that the placing of a norm within an international organisation as a set of rules or principles is simply part of the dynamic of norm cascade. It is not an indication of a widely or deeply internalised norm. ${ }^{21}$ What is needed is both sufficient numbers of states, and deep internalization by 'key’ states. Finnemore and Sikkink stress that some states are 'critical to a norm's adoption' and thereby its effectiveness. ${ }^{22}$ What constitutes a 'key' state 'will vary from issue to issue, but one criterion is that critical states are those without which the achievement of the substantive norm goal is compromised. ${ }^{23}$ Here, then, the UN Security Council permanent members are key states in this context. Taking into account the central role of the Security Council in the operation of R2P, particularly with respect to the responsibility to intervene under Pillar 3, without the adoption of these states the effectiveness of R2P is seriously compromised. Therefore, according to Finnemore and Sikkink, securing the support of the permanent members of the Security Council would be critical to achieve the necessary norm cascade. ${ }^{24}$

\section{Norm emergence: The rise of R2P}

Following the intervention of NATO in Kosovo in 1999, the then UN Secretary General Kofi Annan posed the following question: 'if humanitarian intervention is, indeed, an unacceptable assault on sovereignty, how should we respond to a Rwanda, to a Srebrenica - to gross and

\footnotetext{
${ }^{19}$ See generally, International Commission on Intervention and State Sovereignty, The Responsibility to Protect (International Development Research Centre, 2001); Stahn (n 1) 99; Garwood-Gowers (n 1) 94.

${ }^{20}$ See generally, Thomas Risse, Stephen C Ropp and Kathryn Sikkink (eds), The Persistent Power of Human Rights: From Commitment to Compliance (Cambridge University Press, 2013).

${ }^{21}$ Finnemore and Sikkink (n 5) 895.

${ }^{22}$ Ibid, 901.

${ }^{23} \mathrm{Ibid}$.

${ }^{24}$ Ibid.
} 
The Version of Record of this manuscript has been published and is available in the Journal on the Use of Force and International Law, Spring/Summer 2018, http://www.tandfonline.com/, https://doi.org/10.1080/20531702.2018.1448156

systematic violations of human rights that offend every precept of our common humanity? ${ }^{25}$ It was in trying to answer Kofi Annan's question that the Canadian government established the International Commission on Intervention and State Sovereignty (ICISS). The Commission consisted of a panel of international experts intended 'to reflect a range of geographical, political and professional backgrounds' ${ }^{26}$ From the Commission the responsibility to protect doctrine had its genesis in December 2001 with the publication of its final report entitled 'Responsibility to Protect'. ${ }^{27}$

The R2P doctrine has been an evolving concept since its first presentation to the international community by ICISS. ${ }^{28}$ Underlying the ICISS report was a desire to reformulate the discussion about the conceptualisation of the responsibility of states to respond to mass atrocities. ${ }^{29}$ There were a number of ways in which it sought to do this. To begin with, ICISS attempted to re-focus the view of where responsibility for protection lies, by placing it principally with each state in relation to its own citizens. It is only where there is failing on the part of the state that the international community is then called upon to intervene. ${ }^{30}$ As far as ICISS was concerned this intervention need not necessarily be military but was not limited to non-military intervention either. ${ }^{31}$ ICISS formulated three strands to its concept of responsibility: the responsibility to prevent, the responsibility to react and the responsibility to rebuild. ${ }^{32}$

The 'responsibility to prevent' is the notion that states have a responsibility to ensure that domestic tensions are addressed before they escalate. ${ }^{33}$ Where a state fails in this responsibility this then passes to the international community. The 'responsibility to rebuild'

\footnotetext{
${ }^{25}$ Kofi A Annan, Secretary-General of the United Nations, 'We the Peoples': The Role of the United Nations in the 21st Century (United Nations, 2000) 48. Then British Prime Minister Tony Blair went further and promised that 'if Rwanda happens again we would not walk away as the outside has done many times before'. See Tony Blair, speech given at Labour Party Conference, Brighton, UK (2 October 2001), quoted in Bellamy, 'Responsibility to Protect or Trojan Horse?' (n 1).

${ }^{26}$ Adele Brown, 'Reinventing Humanitarian Intervention: Two Cheers for the Responsibility to Protect?' Research Paper 08/55 (17 June 2008) International Affairs and Defence Section, House of Commons Library, http://researchbriefings.parliament.uk/ResearchBriefing/Summary/RP08-55\#fullreport (accessed 15 November 2016). The participants in the Commission were led by Co-Chairs Gareth Evans, former Foreign Affairs Minister of Australia, and Mohamed Sahnoun of Algeria, Special Advisor to the UN Secretary-General. The ten other ICISS Commissioners were Gisèle Côté-Harper, Lee Hamilton, Michael Ignatieff, Vladimir Lukin, Klaus Naumann, Cyril Ramaphosa, Fidel Ramos, Cornelio Sommaruga, Eduardo Stein and Ramesh Thakur.

${ }^{27}$ ICISS (n 19).

${ }^{28}$ For an outline of the evolutionary process that R2P has undergone, see Hehir (n 1) 122-32; Bellamy, Global Politics and the Responsibility to Protect (n 1) 1-51.

${ }^{29}$ Hehir (n 1) 123.

${ }^{30}$ ICISS (n 19) 16.

${ }^{31}$ Ibid, 8.

32 Ibid, 17; Garwood-Gowers (n 1) 93; Hehir (n 1) 123.

33 Ibid, 124; ICISS (n 19) 19-27.
} 
places a responsibility on an intervening state, or states, to contribute to the process of postconflict recovery. ${ }^{34}$ Of the three strands it is the 'responsibility to react' that has caused the most controversy and is the focus here. Its importance within the R2P concept was emphasised in the ICISS report, where it was stated that 'above all else' R2P establishes for the international community 'a responsibility to react to situations of compelling need for human protection' ${ }^{35}$ According to ICISS, if a state is unwilling or unable to meet its responsibility to protect its citizens then the responsibility moves from the state to the international community. ${ }^{36}$ Not in every situation will military intervention be a legitimate response; ICISS envisaged that military intervention would be confined to the most exceptional situations. It thus outlined six 'Principles for Military Intervention': right authority, just cause, right intention, last resort, proportional means and reasonable prospects. ${ }^{37}$

The doctrine outlined in the ICISS report was subject to detailed evaluation and reinterpretation by the international community. In 2004, the UN High-Level Panel on Threats, Challenges and Change, having considered the ICISS report, published its report in which it agreed that the international community had a responsibility to protect populations when their government failed to do so, but reaffirmed the central role of the UN Security Council in enforcing this responsibility. The final report of the Secretary-General's High Level Panel endorsed R2P at the 2005 World Summit. ${ }^{38}$

Underlying the World Summit's decision to adopt the 'responsibility to protect' was the idea that the international community has a moral duty to ensure atrocities such as those perpetrated in Cambodia, Rwanda, Srebrenica in the former Federal Republic of Yugoslavia and Kosovo were to be prevented or halted. Under R2P it was to be the moral duty of the international community to assist all states to meet their responsibility to protect (that is, the responsibility of a state to protect its population from the four core crimes of genocide, war crimes, ethnic cleansing and crimes against humanity). ${ }^{39}$ Where a state manifestly fails to meet this responsibility to its population, the international community is to take timely and decisive action, including, most controversially, the resort to forceful intervention. ${ }^{40}$

\footnotetext{
${ }^{34}$ Ibid, 39-45.

${ }^{35}$ Ibid, 29.

${ }^{36}$ Hehir (n 1) 124.

${ }^{37}$ ICISS (n 19) 32; Hehir (n 1) 124.

382005 World Summit Outcome, UNGA Res 60/1, UN Doc A/RES/60/1 (24 October 2005). The key paragraphs are 138 and 139.

39 Bellamy, 'Added Value or Hot Air?' (n 1) 333.

40 Ibid.
} 
The Version of Record of this manuscript has been published and is available in the Journal on the Use of Force and International Law, Spring/Summer 2018, http://www.tandfonline.com/, https://doi.org/10.1080/20531702.2018.1448156

The responsibility to protect is threefold, which, in its current formulation, is characterised as a three-pillar structure. ${ }^{41}$ Pillar 1 states that the primary responsibility is that of the state to protect its population from genocide, war crimes, ethnic cleansing and crimes against humanity, and from their incitement; Pillar 2 states that the international community has a responsibility to assist and encourage states to fulfil their responsibility to protect, particularly by helping them to address the underlying causes of genocide and mass atrocities, build the capacity to prevent these crimes, and address problems before they escalate. ${ }^{42}$ The principal emphasis of R2P, therefore, is one of prevention through early monitoring and assistance. ${ }^{43}$ However, where prevention does not succeed, Pillar 3 of R2P provides that the international community has a responsibility to take timely and decisive action to protect populations from the four crimes through diplomatic, humanitarian and other peaceful means (principally in accordance with Chapters VI and VIII of the UN Charter). Should peaceful means prove inadequate and where national authorities are manifestly failing to protect their populations, other more forceful means through Chapter VII of the UN Charter, i.e. military intervention, may be adopted.

An interesting feature of the development of the three-pillar structure is the assertion by the Secretary General and some states that the operationalisation of R2P is not to be seen as an either/or approach to the implementation of the three pillars. ${ }^{44}$ A clearly expressed feature of R2P's three-pillar structure is that each pillar is of equal value and it is not necessarily the case that the parameters of each pillar must be exhausted before moving on to the next pillar, in particular with the operation of pillars 2 and 3 and the use of forcible intervention. While forcible intervention may be a 'last resort', its use does not require 'a prior futile use of other means' - such as those under Pillar $2 .{ }^{45}$ R2P thereby has an inherently complex structure. It therefore seems important at this stage to delimit the scope of the rest of this analysis. Here $\mathrm{R} 2 \mathrm{P}$, under its three-pillar structure, is viewed as more than just one norm. Arguably, it is an agglomeration of norms for humanitarian protection, some aspects of which have greater

\footnotetext{
${ }^{41}$ See UN Doc A/RES/60/1 (n 38) paras 138-9. See also Hehir (n 1) 130.

${ }^{42}$ See Ban Ki-moon, 'Report of the Secretary-General of the United Nations: Implementing the Responsibility to Protect', UN Doc A/63/677 (12 January 2009) 8.

${ }^{43}$ See Hehir (n 1) 130 (describing the response in the General Assembly to the Outcome Document 2005: 'It was consistently stressed [by states] that prevention was a key component of R2P; many states emphasised that R2P involved much more than military intervention and, further, that its greatest potential efficacy lay in its capacity to prevent, rather than halt, humanitarian crisis'). See also ibid, 132-4 (providing critical analysis of the emphasis on prevention within the R2P doctrine).

${ }^{44}$ See, e.g. General Assembly: Statement by Ambassador Berger at the 4th Informal Interactive Dialogue on the Responsibility to Protect (5 September, 2012).

${ }^{45}$ Ibid.
} 
The Version of Record of this manuscript has been published and is available in the Journal on the Use of Force and International Law, Spring/Summer 2018, http://www.tandfonline.com/, https://doi.org/10.1080/20531702.2018.1448156

normative resolution than others. ${ }^{46}$ This view would seem to be borne out by the UN Secretary General's own treatment of the doctrine through his series of special reports on R2P, which focussed upon each of the aspects of the three-pillar structure separately, whilst within each report ensuring that the treatment of each of the pillars addressed were analysed not only as a particular normative goal but also within the broader normative construct of R2P. ${ }^{47}$ Seeing R2P in this way enables one then to consider the different tenets of R2P for which, arguably, there are different norm dynamics at play. The most controversial aspect, ${ }^{48}$ and the subject of analysis here, is R2P's humanitarian intervention norm encompassing the role and responsibility of the international community to react and use military intervention where the humanitarian situation demands such, due to a state's perpetration of, or inability to prevent the perpetration of, the four core crimes against its population.

\section{Evaluating R2P's embeddedness}

That R2P has emerged as an international norm is still somewhat contested in both international law and international relations literature. ${ }^{49}$ On the one hand, it is asserted by Risse and Roppe that 'a new international norm has emerged, the Responsibility to Protect (R2P), referring to the responsibility of the international community to intervene - by military means is necessary - if state rulers are unwilling or incapable of protecting their citizens from gross human rights violations. ${ }^{50}$ On the other hand, Stahn has previously argued that R2P 'remains uncertain from a normative point of view ... Responsibility to protect is thus in many ways still a political catchword rather than a legal norm. ${ }^{51}$ The question of R2Ps acceptance as a norm is probably best encapsulated by the Aidan Herir's questioning of R2P as constituting a 'norm or nebulous? ${ }^{52}$ According to Herir a key factor militating against it constituting a norm is that the conceptual framework for R2P is underdeveloped and indeterminate, particularly in respect of the matter of intervention. ${ }^{53}$ That said, since 2005 there has been much work done by the UN to try to provide greater conceptual clarity with the regular provision of detailed reports by the

\footnotetext{
${ }^{46}$ Kantareva (n 1) 1.

47 See $\mathrm{n} 54$ for the range of reports published by the Secretary General providing greater conceptual clarity.

48 Garwood-Gowers (n 1) 93.

${ }^{49}$ Hehir (n 1) 137.

${ }^{50}$ Risse, Ropp and Sikkink (n 20) 3. See also Hehir (n 1) 137.

${ }^{51}$ Stahn (n 1) 120. See also Garwood-Gowers (n 1) 95.

52 Garwood-Gowers (n 1) 96; Hehir (n 1) 120.

53 Ibid, 138.
} 
The Version of Record of this manuscript has been published and is available in the Journal on the Use of Force and International Law, Spring/Summer 2018, http://www.tandfonline.com/, https://doi.org/10.1080/20531702.2018.1448156

Secretary-General addressing the respective pillars and norms that make up R2P. In particular, since 2009 the Secretary-General has published annual reports focussed upon the matter of implementation and operationalisation of R2P. ${ }^{54}$

In addition to the conceptual refinement of R2P there has also been considerable rhetorical support for R2P at the international level amongst states. Since 2005, states have provided much fulsome support for the doctrine within the UN and other international fora. ${ }^{55}$ An indicative example is the UK, which has been effusive in its support for the development of R2P at various stages within the UN. This is both with respect to R2P more broadly (i.e. the doctrine encompassing all three pillars) and with respect to the responsibility to intervene under Pillar 3, more specifically. The UK thus is a prime example of what Finnemore and Sikkink would describe as a 'norm entrepreneur'. ${ }^{56}$ By way of illustration, the UK engaged centrally with the development of R2P through the ICISS. ${ }^{57}$ It has also been vocal in its commitment to R2P within the UN since the agreement of the World Outcome Document $2005 .{ }^{58}$ This was

54 UN Doc A/63/677 (n 42) 8; 'Report of the Secretary-General: Early Warning, Assessment and the Responsibility to Protect', UN Doc A/64/864 (14 July 2010); 'Report of the Secretary General: The Role of Regional and Sub-Regional Arrangements in Implementing the Responsibility to Protect', UN Doc A/65/877S/2011/393 (27 June 2011); 'Report of the Secretary General: Responsibility to Protect: Timely and Decisive Response', UN Doc A/66/874-S/2012/578 (25 July 2012); 'Report of the Secretary General: Responsibility to Protect: State Responsibility and Prevention', UN Doc A/67/929-S/2013/399 (13 July 2013); 'Report of the Secretary General: Fulfilling our Collective Responsibility: International Assistance and the Responsibility to Protect', UN Doc A/68/947-S/2014/449 (11 July 2014); 'Report of the Secretary General: A Vital and Enduring Commitment: Implementing the Responsibility to Protect', UN Doc A/69/981-S/2015/500 (13 July 2015).

55 For a detailed list of government statements referring to R2P, see the International Coalition for the Responsibility to Protect website, www.responsibilitytoprotect.org/index.php/about-rtop/government-statementson-rtop (accessed 10 November 2016).

56 Finnemore and Sikkink (n 5) 896.

${ }^{57}$ It is worth highlighting that prior to the development of the doctrine of R2P the UK had been one of the few states within the international system to argue the existence of a right of humanitarian intervention within international law. During the NATO intervention in Kosovo, the UK was one of the few NATO states to articulate a legal basis for the right of humanitarian intervention without express Security Council authorisation. See 'Human Rights', Foreign and Commonwealth Office Annual Report 2000 - The framework for humanitarian intervention was built on six principles:

1. An intervention is an admission of failure of prevention. We need a strengthened culture of conflict prevention.

2. We should maintain the principle that armed force should only be used as a last resort.

3. The immediate responsibility for halting violence rests with the state in which it occurs.

4. When faced with an overwhelming humanitarian catastrophe, which a government has shown it is unwilling or unable to prevent or is actively promoting, the international community should intervene. Intervention in internal affairs is a sensitive issue, so there must be convincing evidence of extreme humanitarian distress on a large scale, requiring urgent relief. It must be objectively clear that there is no practicable alternative to the use of force to save lives.

5. Any use of force should be proportionate to achieving the humanitarian purpose and carried out in accordance with international law. The military action must be likely to achieve its objectives.

6. Any use of force should be collective. No individual country can reserve to itself the right to act on behalf of the international community.

${ }^{58}$ For a helpful source of UK government statements on R2P within the United Nations, see 'United Kingdom's Statements on RtoP from 2005-Present', International Coalition for the Responsibility to Protect (ICRtoP), 
The Version of Record of this manuscript has been published and is available in the Journal on the Use of Force and International Law, Spring/Summer 2018, http://www.tandfonline.com/, https://doi.org/10.1080/20531702.2018.1448156

reaffirmed by Lord Malloch-Brown, the UK Ambassador to the UN, speaking at the General Assembly on 23 July 2009, who described R2P as a 'groundbreaking' achievement, of which the UN 'should be rightly proud'. ${ }^{59}$ He went on to say that 'the Responsibility to protect activity encompasses a wide range of possible actions designed to help States protect their populations - all, as the Secretary-General makes clear, in accordance with the UN Charter. Collective action should be determined by an assessment of the situation on the ground and of the best tools suited to address that. ${ }^{60}$ More recently the UK government's commitment to R2P was reaffirmed by a statement made at the UN General Assembly Interactive Dialogue on Responsibility to Protect on 11 September 2013: 'Since... the Responsibility to Protect has emerged as an important global principle. We in the UK are fully committed to implementing the Responsibility to Protect. ${ }^{, 61}$ Within the UN, since 2005 the UK has made some 25 statements supporting or affirming R2P. ${ }^{62}$

Advocates of R2P would point beyond these rhetorical affirmations of the idea, however, and argue that testament to R2P's influence is exemplified in its central role in the international community's response to the crises in Libya and the Côte d'Ivoire in 2010$2011 .^{63}$ Its advocates argue that at the heart of the UN's response to each crises was R2P's normative imperative. ${ }^{64}$ With respect to Libya it is seen as pertinent that in Resolution 1970 (2011) and Resolution 1973 (2011) the Security Council made explicit reference to R2P. ${ }^{65}$ In relation to the UN Operation in Côte d'Ivoire (responding to election violence in the country) it is also argued that R2P played a central role in Resolution 1975 adopted by the Security Council. ${ }^{66}$ According to Alex Bellamy, for example,

[t]hese three resolutions, passed without a single negative vote, clearly demonstrated the Council's determination to act on its responsibility to protect populations, including

\footnotetext{
www.responsibilitytoprotect.org/index.php/component/content/article/134-americas/5439--united-kingdomsstatements-on-rtop-from-2005-present (accessed 16 September 2016).

${ }^{59}$ UNGA Verbatim Record, UN Doc A/63/PV.97 (23 July 2009) 6.

${ }^{60}$ Ibid, 7.

${ }^{61}$ Statement by Ambassador Wilson, of the UK Mission to the UN, at the UN General Assembly Interactive Dialogue on Responsibility to Protect, www.gov.uk/government/speeches/uk-fully-committed-to-implementingthe-responsibility-to-protect (accessed 16 September 2016).

62 See $n 55$.

63 Aidan Hehir, 'The Permanence of Inconsistency: Libya, The Security Council and the Responsibility to Protect' (2013) 38 International Security 137; Alex J Bellamy and Paul D Williams, 'The New Politics of Protection? Côte d'Ivoire, Libya and the Responsibility to Protect' (2011) 87 International Affairs 825.

${ }^{64}$ Bellamy, Towards a 'Living Reality' (n 1) 16.

65 Ibid.

${ }^{66}$ Ibid.
} 
The Version of Record of this manuscript has been published and is available in the Journal on the Use of Force and International Law, Spring/Summer 2018, http://www.tandfonline.com/, https://doi.org/10.1080/20531702.2018.1448156

through the use of force when necessary and possible. They signalled a new phase in the Council's history from which there could be no return. ${ }^{67}$

Such an optimistic view of R2P's influence as a norm is not uncontested, however.

\section{Evaluating the internalisation of R2P}

At the outset of this article it was posited that there are three phases of R2P's norm emergence that must be analysed to reach a full understanding of R2P's impact as a humanitarian intervention norm. Up to this point the analysis herein has focussed upon the phase one and two of R2P's 'norm life-cycle': the emergence of the norm and its embeddedness at the international level. Through its emergence as an idea from ICISS and to its subsequent doctrinal development, coupled with its support and acclamation through various UN Secretary General Reports and General Assembly resolutions, R2P could reasonably be argued to have emerged and become embedded as an important doctrine in international discourse. However, in order to be considered a fully emerged international norm the emergence of R2P and its embeddedness in the international system, i.e. R2P's 'norm cascade', must lead to its deep internalisation by states. The third phase to be examined, then, is the extent of internalisation of R2P by states. This section will consider whether the answer to the limited extent of the role played by R2P in the conditioning key states' policy choices and decision-making within the Security Council actions involving intervention may in part be due to the limited extent of its internalisation by states in this sense.

When one considers the Security Council resolutions in detail and the role of R2P within them, one is struck by the limited extent to which R2P forms a basis for Security Council action. In the main the only aspect of R2P that is referred to is the responsibility of the state in question to fulfil its responsibility to protect its own population. According to Morris, commenting on Libya,

the official record of UNSC's deliberations over Resolution 1973 gives little support to assertions that R2P was a major influencing factor on decisions over the most

\footnotetext{
${ }^{67}$ Ibid, 19. Bellamy also points to UNSC Res 1996, UN Doc S/RES/1996 (8 July 2011) (which established a UN peace operation for South Sudan); UNSC Res 2014, UN Doc S/RES/2014 (21 October 2011) (addressing the situation in Yemen); and UNSC Res 2085, UN Doc S/RES/2085 (20 December 2012) (on Mali as being based upon R2P and further support for R2P's influence as a norm).
} 
The Version of Record of this manuscript has been published and is available in the Journal on the Use of Force and International Law, Spring/Summer 2018, http://www.tandfonline.com/, https://doi.org/10.1080/20531702.2018.1448156

appropriate form of intervention. Throughout the Council's deliberations only France and Colombia referred to the concept, and even then only in respect of Libya's responsibility to protect its citizens. ${ }^{68}$

Certainly in respect of Libya and, then, subsequently in respect of Côte d'Ivoire and Syria, no reference is made in the resolutions to the international community's responsibility to protect. ${ }^{69}$ For example, with respect to Libya and Security Council Resolution 1970 (2011), the reference to R2P merely consisted of the Security Council, '[r]ecalling the Libyan authorities' responsibility to protect its population' ${ }^{70}$ In the now infamous resolution authorising NATO intervention, Council Resolution 1973 (2011), the extent of the resolution's reference to R2P was: 'Reiterating the responsibility of the Libyan authorities to protect the Libyan population and reaffirming that parties to armed conflicts bear the primary responsibility to take all feasible steps to ensure the protection of civilians' ${ }^{71}$

If one looks at the public records of Council meetings on Libya it is notable that there is a pattern of referring overwhelmingly to the primary responsibility of the state to protect its citizens with very limited reference to the responsibility of the international community to protect. $^{72}$ Morris suggests that this pattern of selective invocation of R2P's tenets is

all the more notable given the Secretary General's explicit citation before the Council of the responsibilities to protect which attach to both national governments and the

\footnotetext{
${ }^{68}$ Morris (n 1) 1272.

${ }^{69}$ Ibid ('This practice of referring only to R2P's pillar one elements was mirrored in the textual composition of the Council's resolutions on Libya, with Resolutions 1970, 1973, 2016 and 2040 all referring to the responsibility of the state, but making no mention of the broader responsibility said to fall on the wider international community when states fail to meet their pillar on responsibilities').

70 UNSC Res 1973, UN Doc S/RES/1973 (17 March 2011). See 'Swift, Decisive Action, Security Council Imposes Tough Measures on Libyan Regime, Adopting Resolution 1970 in Wake of Crackdown on Protesters', Security Council meetings coverage, 6491st mtg, UN Doc SC/10187/REV.1 (26 February 2011) www.un.org/press/en/2011/sc10187.doc.htm (reporting, regarding the Security Council vote on Resolution 1973 (2011), that ' $[\mathrm{i}] \mathrm{n}$ their explanations of vote, Council members welcomed the unanimity of the action and expressed solidarity with the people of Libya, hoping that their "swift and decisive" intervention would help bring them relief. Many expressed hope that the resolution was a strong step in affirming the responsibility of states to protect their people as well as the legitimate role of the Council to step in when they failed to meet that responsibility.' However, in the reported statements of the 15-member Council only one member made reference to R2P: 'GÉRARD ARAUD ( France) welcomed the fact that the Council had unanimously answered yesterday's appeal by the Libyan representative. The referral of the matter to the International Criminal Court might ensure that those responsible for the crimes were brought to justice. The Court had once again showed the rationale for its existence. The resolution recalled the accountability of each state for the protection of its population and the role of the international community when that responsibility was not met. He hoped the vote would open a new era for the international community as a whole').

${ }^{71}$ UN Doc S/RES/1973 (n 70).

${ }^{72}$ Morris (n 1) 1272.
} 
international community. Having been clearly reminded of their obligations, the majority of UNSC member states chose not to draw on such language in justifying their approaches to the crisis in Libya. ${ }^{73}$

Consequently, when one undertakes a textual analysis of Council resolutions on Libya as a whole it seems unclear that the basis for intervention was R2P. When one further combines this with the statements from meetings had by states surrounding the Libya situation it seems even less clear that the basis for intervention in Libya was R2P (as opposed to other humanitarian, strategic, political and security factors).

Similarly, a limited role for R2P was also apparent in Security Council Resolution 1975 (2011), addressing the situation in Côte d'Ivoire. Again, the most explicit reference to R2P is to the 'primary responsibility of each State to protect civilians'. ${ }^{74}$ And notably in the operative paragraphs authorising intervention there is no further reference to R2P and certainly no reference to the responsibility of the international community. Instead the basis for action is the more formulaic language of collective security. Once again, the 'textual composition'75 of the Council resolutions and deliberations does not support the optimistic claim of the centrality of the R2P in the considerations of states and the Security Council. However, Libya and Côte d'Ivoire both have been held up as defining moments for R2P - in particular with respect to Libya. In 2011 UN Secretary General Ban Ki-moon gave the following optimistic appraisal of the impact of R2P:

In 2011, history took a turn for the better. The responsibility to protect came of age; the principle was tested as never before. The results were uneven, but at the end of the day, tens of thousands of lives were saved. We gave hope to people long oppressed. In Libya, Côte d'Ivoire, South Sudan, Yemen and Syria, by our words and actions, we demonstrated that human protection is a defining purpose of the United Nations in the twenty-first century. ${ }^{76}$

\footnotetext{
${ }^{73}$ Ibid.

${ }^{74}$ UNSC Res 1975, UN Doc S/RES/1975 (30 March 2011).

${ }^{75}$ Morris (n 1) 1272.

${ }^{76}$ Ban Ki-moon, United Nations Secretary General, address to the Stanley Foundation Conference on the Responsibility to Protect, New York (18 January 2012).
} 
The Version of Record of this manuscript has been published and is available in the Journal on the Use of Force and International Law, Spring/Summer 2018, http://www.tandfonline.com/, https://doi.org/10.1080/20531702.2018.1448156

Nonetheless, the rush to attribute good cause to R2P has proved something of a double edged sword. As has been well documented, the eventual intervention in Libya subsequently proved to be controversial in both its scope and effect. Arguably the intervention in Libya left R2P somewhat tarnished as a doctrine of humanitarian intervention. ${ }^{77}$ There is an apparent irony to this because, as has been suggested in the foregoing, R2P played only a limited role in the relevant Security Council resolutions and deliberations of states. However, as Morris notes, the association of R2P with the more controversial aspects of the intervention in Libya cast a 'dark shadow $^{\text {,78 }}$ over R2P and nowhere has this been more evident than with respect to the situation in Syria.

The situation in Syria is very difficult as now the humanitarian crisis has taken on complex dimensions with the rise of ISIL and the threat of international terrorism, regional and international strategic manoeuvrings and the ever increasing humanitarian crisis. Multiple states have intervened, both regional and international actors. Since 2011, when the UN Secretary General was first briefed on the deteriorating situation in Syria, ${ }^{79}$ the response of the Security Council has been characterised by division and inaction, to the extent that the authorisation of a humanitarian intervention could not be agreed. Early attempts were made to secure non-coercive resolutions identifying the grave humanitarian situation but these were frustrated by Chinese and Russian vetoes. ${ }^{80}$ Undoubtedly there were other strategic, political and security factors at play that cloud any straightforward analysis of the Council's response to Syria. That said, however, Morris suggests that when one examines the justifications for why Russia and China rejected attempts for Council authorisation of intervention, even of a noncoercive kind, they reflect not just a rejection of the specific case of intervention in Syria but the rejection of the 'wider normative agenda'. ${ }^{81}$ That is, R2P itself.

When examining the invocation of R2P within Security Council resolutions on the situation in Syria, again, as with Libya and Côte d'Ivoire, it is striking how limited this is. ${ }^{82}$ In

\footnotetext{
${ }^{77}$ See Garwood-Gowers (n 1) 97 (noting that '[w]hile the passage of Resolution 1973 authorizing military force against the Gaddafi regime was initially seen as a triumph for R2P, under the surface there were deep divisions within the UNSC. NATO's support for the Libyan rebels and the eventual removal of Gaddafi prompted renewed concerns among the BRICS (Brazil, Russia, India, China, South Africa) and other non-Western states over the potential for R2P to be used as a pretext for regime change. This led to extensive "blow-back" against R2P, which was evident in the UNSC's inability to agree on any effective civilian protection measures on Syria').

${ }^{78}$ Morris (n 1) 1274.

${ }^{79}$ UNSC Verbatim Record, UN Doc S/PV.6524 (27 April 2011).

${ }^{80}$ UNSC Draft Res, UN Doc S/2011/612 (4 October 2011).

${ }^{81}$ Morris (n 1) 1276.

${ }^{82}$ Ibid (noting that only seven Council Members between 2011 and 2013 made explicit or clear reference to R2P (all citing the Pillar 1 obligation and not more): Colombia, France, Togo, Rwanda, Japan, and Brazil).
} 
The Version of Record of this manuscript has been published and is available in the Journal on the Use of Force and International Law, Spring/Summer 2018, http://www.tandfonline.com/, https://doi.org/10.1080/20531702.2018.1448156

Council Resolution 2139 (2014), for example, the only reference to R2P is with respect to Syria’s primary responsibility to protect its citizens. In the subsequent Council Resolution 2165 (2014), again there was limited reference to R2P, merely containing a statement '[r]eaffirming the primary responsibility of the Syrian authorities' ${ }^{83}$ In the following draft resolution, vetoed by Russia and China (seeking to refer the situation in Syria to the Prosecutor of the International Criminal Court) there was no reference to R2P. ${ }^{84}$ Where R2P is referred to in the subsequent Resolutions 2254 and 2258 (2015), again, it is solely in respect to the primary responsibility of 'the Syrian authorities to protect the population in Syria' ${ }^{85}$

Thus, as with both the Libya and Côte d'Ivoire situations, the assertion of R2P in Council resolutions has also been limited with respect to Syria. Where R2P has been invoked, likewise with Libya and Côte d'Ivoire, its invocation has been with respect to asserting the primary responsibility of Syria to fulfil its 'primary' responsibility to protect its citizens. Notably, and of particular importance, is the fact that no Council resolution asserts the responsibility of the international community under Pillar 3 of R2P.

Possibly more telling is that in Council meetings discussing situation in Syria, in which states have had the opportunity to express their underlying attitudes, policies, perspectives and preferences with respect the resolutions, there was equally very limited reference to R2P. These meetings can be the source of states speaking more freely and enabling states to express any dissent. However, with respect to all the resolutions noted, the opinions expressed by states were distinctly lacking reference to R2P, in the main.

In similar vein to the Resolutions, in the opinions expressed by states in the associated meetings emphasis was placed upon the primary responsibility of Syria to protect its citizens. With respect to the Council meeting for Resolution 2139, for example, Argentina and Lithuania were the only states that made explicit reference to R2P and in both cases this was limited to asserting Syria's primary responsibility to protect its citizens. ${ }^{86}$ Regarding the meeting for Council Resolution 2165 only Lithuania made reference R2P, asserting that the 'primary responsibility lies with the Syrian government' and more broadly to the 'responsibility of the parties to the conflict' to protect the citizens of Syria. ${ }^{87}$ In the meeting for Council Resolution 2254, only Malaysia made reference to R2P, which again was limited in its scope, emphasising

\footnotetext{
${ }^{83}$ UNSC Res 2165, UN Doc S/RES/2165 (14 July 2014).

${ }^{84}$ UNSC Draft Res, UN Doc S/2014/348 (22 May 2014).

85 UNSC Res 2254, UN Doc S/RES/2254 (18 December 2015); UNSC Res 2258, UN Doc S/RES/2258 (22 December 2015).

${ }^{86}$ UNSC Verbatim Record, UN Doc S/PV.7116 (22 February 2014).

${ }^{87}$ UNSC Verbatim Record, UN Doc S/PV.7216 (14 July 2014).
} 
the Syrian government's 'primary responsibility and obligation to protect its own people. ${ }^{88}$ Whereas in the meeting for Resolution 2258 there was no reference made to R2P at all. ${ }^{89}$ Only in one case was reference made to the Council having a responsibility to protect. That was by Australia in regard to the previously mentioned failed draft resolution seeking to refer the Syria situation to the ICC which was vetoed by Russia and China. ${ }^{90}$

From the foregoing it seems clear that R2P has had a limited role within the deliberations of the Security Council with respect to the situation in Syria. This is highlighted in the limited number of times that R2P has been cited by the Council or by states and has been confined to references to the primary responsibility of Syria to protect its own citizens. Moreover, what is absent in the resolutions and Council meetings is the invocation of the responsibility to protect of the international community under Pillar 3. States that were once forceful in their assertion of the responsibility to protect with respect to Libya have been notably less so with respect to Syria. ${ }^{91}$ Whilst this textual analysis of Council resolutions and meetings cannot be considered definitive for arriving at a conclusion as to whether R2P has the degree of influence attributed to it by its advocates, it certainly helps to build a picture. That picture indicates that whilst the idea of responsibility to protect has some place in the consciousness of states, it is apparently mostly limited to Pillar 1 and arguably has little impact with respect to Pillar 3. The picture drawn by Council resolutions and meetings is certainly indicative of a dissonance between states' acclamation of the idea in its concept and the role R2P plays in their decision-making. Taking the situation in Syria, for example: whilst there was significant clamour for humanitarian intervention within international society more broadly, the response of the Security Council to this has been inadequate.

\section{Conclusion}

The aim of this article was to examine the extent to which R2P, a much-lauded concept of humanitarian protection, has played a role in shaping the decision-making of states. It is through identifying this role that one is then able to determine the extent of R2P's

\footnotetext{
${ }^{88}$ UNSC Verbatim Record, UN Doc S/PV.7588 (18 December 2015).

${ }^{89}$ UNSC Verbatim Record, UN Doc S/PV.7595 (22 December 2015).

${ }^{90}$ UNSC Verbatim Record, UN Doc S/PV.7180 (22 May 2014).

${ }^{91}$ Morris (n 1) 1276 (noting, for example, 'Colombia, a relatively vociferous advocate of R2P over Libya, became markedly more circumspect in its citation of R2P as the debates over Syria continued').
} 
The Version of Record of this manuscript has been published and is available in the Journal on the Use of Force and International Law, Spring/Summer 2018, http://www.tandfonline.com/, https://doi.org/10.1080/20531702.2018.1448156

transformation from a concept of ideational value to the quality of a norm with the power to influence state behaviour.

That R2P has significant ideational value attributed to it is clear but the question of its impact as a norm is less so. R2P has gone through numerous iterations and conceptual developments; there is little questioning of its content. Much energy and time has been devoted by states and advocates to this task. Yet when one examines the role that R2P has played within the decision-making surrounding the situations discussed herein - Libya, Côte d'Ivoire and Syria - R2P has apparently had little influence in states' discourse at the international level, with it apparently having very limited 'enabling and constraining' effect upon state behaviour. As has been shown, in Security Council resolutions and meetings, states have made only limited reference to the R2P and, in particular, no reference to the international community's responsibility to protect under the third pillar of the concept.

According to Morris there are two plausible explanations for the limited invocation of $\mathrm{R} 2 \mathrm{P}$ by states. The first is that it is 'conceivable that while R2P provided the conceptual framework through which some states framed their policy options, and that for some of them it even served as a motivating factor, it was nevertheless deemed inexpedient to cite the concept, especially in pillar three guise, given the controversy surrounding it. ${ }^{92}$ The corollary of this is that R2P remains controversial and highly contested, especially with respect to its third pillar. This may indicate that R2P has not attained the level of norm cascade that is often presumed in the writings of many of its proponents. ${ }^{93}$ The second explanation is that in respect of each situation discussed, 'states did not cite R2P... because it did not figure significantly in their thinking', ${ }^{94}$ signalling a lack of internalisation.

That R2P has strong value as a doctrine of human security and protection is not contested here. However, whilst R2P has undergone considerable development as a concept of human security and protection it seemingly has only had limited effect on the behaviour of key states as represented through their discourse surrounding the action, or lack of action, of the Security Council. This therefore undermines the claim to R2P as a fully formed international norm beyond its conceptual architecture. In order for R2P to be considered a norm that truly has emerged, not only must it have the conceptual framework and ideational support and

\footnotetext{
92 Ibid, 1273.

93 Ibid.

${ }^{94}$ Ibid.
} 
The Version of Record of this manuscript has been published and is available in the Journal on the Use of Force and International Law, Spring/Summer 2018, http://www.tandfonline.com/, https://doi.org/10.1080/20531702.2018.1448156

acclamation it has, it must also influence the behaviour of states in their decision-making, which apparently it has not.

\section{Acknowledgements}

I am very grateful to Dr Sarah Sargent, Professor James A Green, Professor Duncan French and Professor Matthew Hall for their invaluable comments and constructive criticism on earlier drafts of this article. I would also like to thank the anonymous reviewers for their helpful reviews. 